Brit. J. industr. Med., 1964, 21, 20.

\title{
PERITONEAL TUMOURS IN ASBESTOSIS
}

\author{
BY \\ J. B. ENTICKNAP and W. J. SMITHER \\ From East Ham Memorial Hospital and Dagenham, Essex, England
}

(RECEIVED FOR PUBLICATION JANUARY 4, 1963)

\begin{abstract}
Eleven cases of diffuse abdominal tumours in association with exposure to asbestos were discovered in the years 1958 to 1963 . There were eight men and three women, all of whom had worked at the same factory. In seven of the men the age at death ranged from 38 to 78 years; one man is still alive at the age of 46 . The women died at 44,61 , and 67 . The survival time after the first exposure varied from 20 to 46 years. The shortest period of exposure was 10 months and the longest 32 years. All three of the main commercial types of asbestos had been involved in their working operations. Histological confirmation of the nature of the tumour has been obtained at necropsy in nine of the 10 deceased and at biopsy in six, including the survivor. A remarkable feature of these cases is the minimal fibrosis found in the lungs. In three men and one woman, asbestosis was not diagnosed during life, and no patient was completely disabled by pulmonary fibrosis.
\end{abstract}

Von Rokitansky in 1854 described primary tumours of the peritoneum which he called 'colloid cancer'. The first case of malignant primary peritoneal tumour reported in this century was described by Miller and Wynn (1908). Since then a considerable number of such tumours has been found. Winslow and Taylor (1960) reviewed the literature and found 13 cases diagnosed as primary peritoneal malignancies in which clinical and pathological data together with complete necropsy reports were recorded. They added 12 more from the files of the U.S. Armed Forces Institute of Pathology. In only one of their cases was evidence of exposure to asbestos demonstrated, although sections from the lungs were examined in each case (personal communication).

An association between asbestosis of the lungs and tumour formation was first reported by Lynch and Smith in 1935. Gloyne (1951) reported at necropsy a $14.1 \%$ incidence of tumours in asbestotics, all of which were carcinoma of the lung. Wagner, in a series of recent publications (Wagner, Sleggs, and Marchand, 1960; Sleggs, Marchand, and Wagner, 1961), has reported a large series of tumours of pleural mesothelium in association with exposure to asbestos. In 1954 Leicher reported an abdominal tumour in a patient with pulmonary asbestosis and thought that asbestos was also present in the tumour. Bonser, Faulds, and Stewart described in 1955 a series of 72 necropsies on asbestotics in which four cases of abdominal neoplasms were found. In a cohort of 1,495 asbestos workers Mancuso and Coulter (1963) found five neoplasms of the peritoneum among members who died at ages from 25 to 64 years, compared with an expected incidence of 0.08. Selikoff, Churge, and Hammond (1963) reported one case of diffuse peritoneal mesothelioma in a group of 632 asbestos workers who had been exposed for at least 20 years in industry. Among 42 cases of asbestosis at necropsy Keal (1960) found 11 cases of abdominal tumours arising at various sites. One of Keal's asbestotics with peritoneal tumour was known to us. Heard and Williams (1961), reviewing pathology and lung function in asbestosis, described a subject with a peritoneal tumour who was also known to us. In this paper we refer to these two cases and describe nine others not previously reported.

\section{Source of Material}

Certified cases of asbestosis must be reported to H.M. Coroner at death under the Births and Deaths Registration Act 1953. Necropsy follows as a matter of routine. There is widespread knowledge of the hazard in the local working community. Industrial death benefit under the Industrial Diseases Regulations of 1948 is payable if asbestosis is shown to be the cause of death or a material contribution thereto. For these reasons many other workers in this section of the industry who die at home or in hospital from 
whatever cause are referred for necropsy. One of us is usually present at the examination or is immediately informed of the circumstances. Ten of the cases described were discovered in this way. The surviving patient is an asbestotic whose complaint of dyspepsia led to investigation in the light of previous experience.

\section{Type of Exposure}

There are three commercially important types of asbestos: chrysotile, crocidolite, and amosite. The latter two are grouped as amphibole asbestos. They differ in geological formation, in chemical composition, in crystalline form, in fibre size, and in many other respects. Wagner et al. (1960) have reported primary mesothelial tumours associated with exposure to crocidolite. In North America primary peritoneal tumours have been reported by Cartier (personal communication) and by Mancuso (Mancuso and Coulter, 1963 and personal communication) in workers exposed to chrysotile. So far there have been no cases reported where the exposure was only to amosite. Cowing (personal communication), in a report not yet published, has found no cases in his experience of workers exposed for many years solely to amosite in South Africa.

The cases in this series had all been exposed at the same factory to dust from all three types of asbestos.
It has proved impossible to ascertain the degree of exposure to any one type. It cannot be too strongly emphasized that the amount of exposure to asbestos was often small. The exposures and histories are outlined in Table 1. They are presented in order of the length of exposure.

\section{Clinical Features}

All the cases presented with abdominal pain, discomfort or ascites (Table 2). The time from the first exposure to the onset of symptoms was always long, from 20 to 46 years. In the majority of cases the illness ran a course of less than six months. In four of the cases pulmonary asbestosis had not been diagnosed or certified previously; in one case the diagnosis of asbestosis was not submitted for certification in deference to the patient's wishes, and in one case the patient died before the diagnosis of pulmonary asbestosis could be confirmed and certified by the Pneumoconiosis Medical Board. None of the cases was severely affected by pulmonary asbestosis. Disability is assessed by the Pneumoconiosis Medical Board according to regulations made under the National Insurance (Industrial Injuries) Act 1946 which came into force in 1948. This is expressed as a percentage except in the cases of two females whose disability was certified as 'total'. Such 'total' disability is the only alternative

TABLE 1

\begin{tabular}{|c|c|c|c|c|c|c|c|c|}
\hline $\begin{array}{l}\text { No. } \\
\text { and } \\
\text { Sex }\end{array}$ & Hospital Reference & $\begin{array}{c}\text { Age } \\
\text { at } \\
\text { Death }\end{array}$ & $\begin{array}{l}\text { Years } \\
\text { of } \\
\text { Exposure }\end{array}$ & $\begin{array}{l}\text { Length } \\
\text { of } \\
\text { Exposure }\end{array}$ & $\begin{array}{l}\text { Diagnosis of } \\
\text { Pulmonary } \\
\text { Asbestosis }\end{array}$ & $\begin{array}{l}\text { Year } \\
\text { of } \\
\text { Death }\end{array}$ & $\begin{array}{c}\text { Survival } \\
\text { after } \\
\text { First } \\
\text { Exposure } \\
(y r .)\end{array}$ & $\begin{array}{l}\text { Certified } \\
\text { Disability }\end{array}$ \\
\hline $1 \mathrm{~F}$ & $\begin{array}{l}\text { Queen Mary's } \\
26655\end{array}$ & 44 & 1935 & 10 months & Not diagnosed & 1961 & 25 & Not certified \\
\hline $2 F$ & Not admitted to hospital & 67 & 1916-1919 & 3 years & 1946 & 1962 & 46 & 'Total' \\
\hline 4F & $\begin{array}{l}\text { King George's } \\
98753\end{array}$ & 61 & $1916-1924$ & 8 years & 1956 & 1962 & 46 & 'Total' \\
\hline $5 \mathrm{M}$ & $\begin{array}{l}\text { London } \\
141164\end{array}$ & Alive & $\begin{array}{l}1937-1940 \\
1945-1955\end{array}$ & 13 years & 1955 & $\begin{array}{c}\text { Biopsy } \\
1962\end{array}$ & $\underset{26}{\text { (Alive) }}$ & $30 \%$ \\
\hline $6 \mathrm{M}$ & $\begin{array}{l}\text { London } \\
40336 / 47\end{array}$ & 38 & $\begin{array}{l}1939-1942 \\
1946-1960\end{array}$ & $16 \frac{1}{2}$ years & 1954 & 1961 & 22 & $20 \%$ \\
\hline $8 . \mathbf{M}$ & $\underset{55085}{\text { Harold Wood }}$ & 47 & 1929-1954 & 25 years & Not diagnosed & 1959 & 30 & Not certified \\
\hline $9 \mathbf{M}$ & $\begin{array}{l}\text { London Clinic } \\
2117 / 61\end{array}$ & 57 & $1921-1948$ & 27 years & 1948 & 1961 & 40 & Not certified \\
\hline $10 \mathrm{M}$ & $\begin{array}{l}\text { London } \\
27245 / 56 \\
\quad \text { (Keal, 1960) }\end{array}$ & 50 & $\begin{array}{l}1931-1935 \\
1937-1954\end{array}$ & 31 years & 1954 & 1958 & 27 & $10 \%$ \\
\hline $11 \mathrm{M}$ & $\begin{array}{l}\text { Hammersmith } \\
227252 \\
\quad \text { (Heard and Williams, 1961) }\end{array}$ & 47 & $1927-1959$ & 32 years & Not diagnosed & 1959 & 32 & Not certified \\
\hline
\end{tabular}


TABLE 2

\begin{tabular}{|c|c|c|c|c|c|c|c|c|c|c|}
\hline $\begin{array}{l}\text { No. } \\
\text { and } \\
\text { Sex }\end{array}$ & $\begin{array}{l}\text { Survival after } \\
\text { Onset of } \\
\text { Symptoms }\end{array}$ & $\begin{array}{l}\text { Survival } \\
\text { after } \\
\text { Biopsy }\end{array}$ & Dyspnoea & $\underset{\text { dominal }}{\text { Pain }}$ & Ascites & $\left|\begin{array}{c|}\text { Ab- } \\
\text { dominal } \\
\text { Distension }\end{array}\right|$ & Vomiting & Anorexia & $\begin{array}{c}\text { Constipa- } \\
\text { tion }\end{array}$ & $\begin{array}{l}\text { Weight } \\
\text { Change }\end{array}$ \\
\hline $1 F$ & $2 \downarrow$ months & 2 months & - & + & + & + & 0 & 0 & 0 & Loss \\
\hline $2 F$ & 19 months & No biopsy & + & + & + & + & 0 & + & + & 0 \\
\hline $3 \mathbf{M}$ & 6 months & $2 \frac{1}{2}$ months & - & + & + & + & - & + & 0 & Loss \\
\hline $4 F$ & 3 months & No biopsy & + & + & + & + & + & + & + & Loss \\
\hline $5 \mathrm{M}$ & $\begin{array}{l}\text { Alive after } \\
10 \text { months }\end{array}$ & $\begin{array}{l}\text { Alive after } \\
10 \text { months }\end{array}$ & + & + & + & + & + & - & - & Gain \\
\hline $6 \mathrm{M}$ & 4 months & 3 months & + & + & + & + & + & 0 & 0 & Gain \\
\hline $7 \mathbf{M}$ & 2 months & No biopsy & - & - & + & - & - & + & 0 & Loss \\
\hline $8 \mathbf{M}$ & 6 months & 7 days & - & + & + & - & + & 0 & + & Loss \\
\hline $9 M$ & 6 months & 1 month & + & + & + & + & 0 & 0 & 0 & o \\
\hline $10 \mathrm{M}$ & 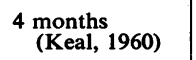 & No biopsy & + & + & + & + & 0 & + & 0 & 0 \\
\hline $11 \mathrm{M}$ & $\begin{array}{l}14 \text { months } \\
\text { (Heard and } \\
\text { Williams, 1961) }\end{array}$ & 6 months & - & + & + & + & 0 & 0 & 0 & Gain \\
\hline
\end{tabular}

+ Present; - Absent; 0 Not recorded.

to 'partial' disability permitted to the assessors under the special legislation introduced to cover those workers whose disease was (a) diagnosed after July 5 , 1948, too late for Workmen's Compensation, and (b) due to exposure which ceased before July 5, 1948, too early to benefit under the present scheme.

\section{Histological Appearances}

Table 3 shows the components of the histological picture and sets out their occurrence in the different cases. In six of them the disease was seen at two stages, e.g. in biopsy and necropsy specimens, and in none of these was the picture identical in both specimens.

In the biopsy material fibrous tissue is relatively scanty and more regular, most of the specimens consisting of pseudo-epithelial formations. The cells in it are almost spherical, and multilayers are common. In most of them no birefringent material is seen, but in the specimen from case $11 \mathrm{M}$ one particularly obvious piece 7 microns long is present.

The tumour material recovered at necropsy, on the other hand, consists mostly of irregular fibrous tissue in which a variable number of clefts have formed. Lining them and on the surface of the tumours are cuboidal, polygonal or columnar cells. This lining is usually formed of a single layer but occasionally is several cells thick. In some places within the tumour there are solid cords and masses of more than a hundred cells but these are not clearly differentiated from the fibrocytic stroma and merge imperceptibly with it. Stains for carbohydrate by the periodic acid Schiff reagent are negative. Histo- chemical tests for hyaluronic acid gave negative results in our hands, but only two of the tumours were fixed as recommended by Wagner, Munday, and Harrington (1962), the remainder being treated with aqueous formalin. Reticulin was demonstrated in variable amounts in five of the tumours examined.

Various physical methods have been used to investigate the tumours. Examination under polarized light reveals a few small birefringent particles but does not show any Newton's colours. These are too small, being less than $\mathbf{3}$ microns long, properly to be called fibres, but their extinction angle is parallel to their long axis, as it is in asbestos fibres. Preparations of fine dust particles of comparable size, kindly provided by Dr. A. A. Hodgson of the Cape Asbestos Company, show very similar appearances, although at this size many of the fibres are not birefringent. Furthermore, the asbestos fragments seen in degenerating pulmonary bodies are usually of similar size and appearance. Material from three of the tumours has been calcined in an attempt to recover asbestos fibres, but none has been demonstrated.

\section{Case Histories}

One typical male case and one typical female case are presented in some detail. The third case presented is unusual in that two primary tumours are described. The remaining case histories are condensed. The clinical features are summarized in Tables 1 and 2 and the pathological findings in Table 3. In the tables the cases are arranged in order of the length of exposure. 
TABLE 3

HISTOLOGICAL FEATURES AND PRESENCE OF BIREFRINGENT MATERIAL IN AVAILABLE BIOPSY AND NECROPSY SPECIMENS FROM 10 CASES

\begin{tabular}{|c|c|c|c|c|c|c|c|c|c|c|c|c|}
\hline \multirow{2}{*}{$\begin{array}{l}\text { No. in } \\
\text { This Series }\end{array}$} & \multirow{2}{*}{$\begin{array}{l}\text { Proportion } \\
\text { Resembling } \\
\text { Fibrous } \\
\text { Tissue }\end{array}$} & \multicolumn{6}{|c|}{ Arrangemfent of Cells Resembling Epithelium } & \multicolumn{4}{|c|}{ Type of Epithelial-like Cells } & \multirow{2}{*}{$\begin{array}{c}\text { Size of } \\
\text { Birefringent } \\
\text { Particles }\end{array}$} \\
\hline & & $\begin{array}{l}\text { Con- } \\
\text { fluent }\end{array}$ & $\begin{array}{l}\text { Alveo- } \\
\text { lar }\end{array}$ & Clefts & $\begin{array}{l}\text { Papil- } \\
\text { lary }\end{array}$ & Fronds & Sheets & $\begin{array}{l}\text { Pave- } \\
\text { ment }\end{array}$ & Cuboid & $\begin{array}{c}\text { Co- } \\
\text { lumnar }\end{array}$ & $\begin{array}{l}\text { Poly- } \\
\text { gonal }\end{array}$ & \\
\hline $\begin{array}{l}\text { 1F } \\
\text { Biopsy } \\
\text { Necropsy* } \dagger\end{array}$ & $50 \%$ & $\begin{array}{l}\mathbf{0} \\
\mathbf{0}\end{array}$ & $\begin{array}{l}\mathbf{0} \\
\mathbf{0}\end{array}$ & $\begin{array}{l}\mathbf{0} \\
\mathbf{0}\end{array}$ & $\begin{array}{l}\mathbf{0} \\
\mathbf{0}\end{array}$ & + & $\stackrel{+}{0}$ & $\begin{array}{l}+ \\
+\end{array}$ & $\begin{array}{l}+ \\
+\end{array}$ & $\begin{array}{l}+ \\
0\end{array}$ & $\begin{array}{l}0 \\
+\end{array}$ & $\begin{array}{r}7 \times 1 \mu \\
30 \times 3 \mu\end{array}$ \\
\hline $\begin{array}{l}\text { 2F } \\
\text { Biopsy not made } \\
\text { Necropsy } * \ddagger\end{array}$ & $90 \%$ & 0 & 0 & + & 0 & 0 & 0 & + & + & 0 & 0 & $3 \times 0.5 u$ \\
\hline $\begin{array}{l}\text { 3M } \\
\text { Biopsy (not } \\
\text { examined by us) } \\
\text { Necropsy* } \dagger\end{array}$ & $\underset{70 \%}{\text { Small }}$ & + & 0 & + & $\begin{array}{l}+ \\
0\end{array}$ & 0 & 0 & 0 & 0 & + & $\begin{array}{l}+ \\
+\end{array}$ & $\begin{array}{l}\text { Not recorded } \\
1 \times 0.5 \mu\end{array}$ \\
\hline $\begin{array}{l}\text { 4F } \\
\text { Biopsy not made } \\
\text { Necropsy }\end{array}$ & $\overline{95 \%}$ & + & 0 & + & 0 & 0 & 0 & + & + & 0 & + & $5 \times 1 \mu$ \\
\hline $\begin{array}{l}\text { 5M } \\
\text { Biopsy } \\
\text { Patient alive }\end{array}$ & $0 \%$ & + & + & + & 0 & 0 & 0 & 0 & + & + & 0 & 0 \\
\hline $\begin{array}{l}\text { 6M } \\
\text { Biopsy } \\
\text { Necropsy } †\end{array}$ & $\begin{array}{l}60 \% \\
100 \%\end{array}$ & + & $\stackrel{+}{0}$ & $\begin{array}{l}+ \\
+\end{array}$ & $\begin{array}{l}0 \\
0\end{array}$ & $\stackrel{+}{0}$ & $\stackrel{+}{0}$ & $\begin{array}{l}0 \\
0\end{array}$ & $\begin{array}{l}+ \\
+\end{array}$ & $\begin{array}{l}\mathbf{0} \\
\mathbf{0}\end{array}$ & + & $\begin{array}{l}4 \times 1 \mu \\
7 \times 5 \mu\end{array}$ \\
\hline $\begin{array}{l}\text { 7M } \\
\text { Biopsy not made } \\
\text { Necropsy }\end{array}$ & $9 \overline{5 \%}$ & 0 & 0 & + & 0 & 0 & 0 & 0 & 0 & 0 & + & $1 \times 0.5 \mu$ \\
\hline $\begin{array}{l}\text { 8M } \\
\text { Biopsy } \\
\text { Necropsy } \dagger\end{array}$ & $\begin{array}{l}\text { Not available } \\
50 \% \text { Differentia- } \\
\text { tion poor }\end{array}$ & $\begin{array}{l}0 \\
+\end{array}$ & $\begin{array}{l}+ \\
+\end{array}$ & $\stackrel{?}{+}$ & $\stackrel{+}{0}$ & $\stackrel{?}{0}$ & $\stackrel{?}{0}$ & $\stackrel{?}{0}$ & $\stackrel{?}{+}$ & + & $\begin{array}{l}? \\
+\end{array}$ & $\begin{array}{l}10 \times 2 \mu \\
(\text { yellow) }\end{array}$ \\
\hline $\begin{array}{l}9 \mathrm{M} \\
\text { Biopsy } \\
\text { Necropsy } \dagger\end{array}$ & $\begin{array}{l}50 \% \\
50 \%\end{array}$ & + & $\begin{array}{l}+ \\
+\end{array}$ & + & $\begin{array}{l}\mathbf{0} \\
\mathbf{0}\end{array}$ & $\begin{array}{l}\mathbf{0} \\
\mathbf{0}\end{array}$ & $\begin{array}{l}\mathbf{0} \\
\mathbf{0}\end{array}$ & $\begin{array}{l}0 \\
0\end{array}$ & $\begin{array}{l}+ \\
+\end{array}$ & $\stackrel{+}{0}$ & $\begin{array}{l}+ \\
+\end{array}$ & $\begin{array}{l}8 \times 2 \mu \\
2 \times 0.5 \mu\end{array}$ \\
\hline $\begin{array}{l}\text { 10M } \\
\text { Biopsy not made } \\
\text { Necropsy }\end{array}$ & $\overline{10 \%}$ & 0 & + & + & 0 & + & 0 & + & + & + & 0 & $5 \times 1 \mu$ \\
\hline
\end{tabular}

* Necrosis present; † Reticulin demonstrated; $\ddagger$ Lymphocytic infiltration.

Case No. 6M [London Hospital 40336/47].-This man died at the age of 38 with 'carcinomatosis peritonei'. He was heavily exposed to mixed asbestos dust as a hopper feeder for six months in 1939. After a break of five months he had a further two years' exposure as a 'card' grinder before his war service. From 1946 to 1961 he worked as as engineer's fitter with minimal exposure to dust. Asbestosis was diagnosed in 1954 on routine periodic examination seven years before death. His terminal illness began with abdominal pain four months before death. Three weeks before admission to the London Hospital in 1961 he complained of the sudden onset of dragging abdominal pain whilst opening his bowels. A nagging pain continued, worse on micturition and defaecation, although evacuation was normal. There was some feeling of abdominal distension, possibly related to a recent weight gain of 1 stone $(6.35 \mathrm{~kg}$.), mild chronic bronchitis, and some exertional dyspnoea but no other relevant symptoms. The family history and social history contained nothing relevant.
On examination he was a pale looking man. The fingers and toes showed mild clubbing. General examination was otherwise normal. The cardiovascular system was normal. The lungs showed poor expansion and scattered rhonchi. The abdomen was distended with ascites and the liver ballotted. Rectal examination was difficult because of spasm and pain; a possible mass was felt. The central nervous system was normal.

The ascites was confirmed by paracentesis, and a clear green fluid containing lymphocytes was obtained. The fluid was not bloody and no neoplastic cells were seen. On June 7, 1961, laparotomy confirmed the presence of carcinomatosis involving the liver and peritoneum. A peritoneal biopsy (London Hospital 3312, June 1961) was reported as a 'trabecular and mono-cellular, occasionally cystic, apparently mucus secreting carcinoma, compatible with primary carcinoma of the stomach' (Fig. 1). Post-operatively the patient developed a chest infection which improved after a course of chemotherapy. Paracentesis was performed on June 20, 1961, 
and mustine, $20 \mathrm{mg}$., was injected. On discharge he was not distressed by any abdominal symptoms and was kept under supervision in the out-patient department. He continued to attend periodically until his death at home on September 17, 1961.

Necropsy was performed on September 18, 1961 by Dr. Enticknap. The body showed considerable wasting, and there was extensive pulmonary asbestosis with markedly increased black pigment markings. The entire peritoneal surface was replaced by continuous white growth in which all the organs were embedded. It particularly appeared to infiltrate the pancreas, but there were no discrete deposits there or in any of the parenchymatous organs. There was a cuirass of growth $30 \mathrm{~cm}$. $\times 20 \mathrm{~cm}$. and $3 \mathrm{~cm}$. thick on the deep surface of the abdominal wall. This was all thought to be due to a carcinoma of the pancreas.

Histological examination confirms extensive pulmonary asbestosis with numerous fragmenting and intact asbestos bodies and some birefringent spicules about $3 \times 0.5$ microns. The bulk of the tumour material is loose fibrous tissue composed of spindle cells among which are hyperchromatic polygonal cells in a proportion of about one in ten. Periodic acid Schiff staining does not reveal any mucus or xymogen granules (Fig. 2.)

Case No. 1F [Queen Mary's Hospital 26655].-This patient died at the age of 44 with 'carcinomatosis peritonei'. She had been exposed to mixed asbestos dust for a short period of 10 months in 1935 in the carding department. Asbestosis had not been diagnosed before death. The terminal illness presented with abdominal pain and distension after meals. On admission to Queen Mary's Hospital on January 15, 1961 she complained of pain in the left groin; the abdomen was distended and a mass was felt. At laparotomy on May 30 there was much free fluid in the abdomen, and widely scattered nodules were seen. A biopsy of the peritoneum was taken. She died in hospital on August 3, 1961.

At necropsy on August 4, 1961, Dr. M. S. Ross found dense pleural adhesions, particularly to the right diaphragm, with moderate pulmonary oedema and congestion. A little fibrosis was seen. The parietal peritoneum was studded with fleshy nodules up to the size of a sixpence, as were the pelvic peritoneum and the surface of the bowel. The omentum was a mass of growth, and there was a large mass $(6 \mathrm{~cm}$.) in the right lobe of the liver, with numerous satellite nodules $(1 \mathrm{~cm}$.). The ovaries were normal.

Histological examination shows moderately advanced asbestosis of the lungs with fragmentation of most of the bodies. Related to them are birefringent particles which are doubtless asbestos. There is advanced bronchopneumonia and long-standing changes of congestive heart failure. The tumour from the peritoneum is predominantly irregular fibrous tissue, with uniformly distributed small birefringent particles. The spindle cells of the main mass have fusiform nuclei of varying size, but they are not hyperchromatic, nor do they look particularly malignant, and there is no pseudo-epithelial growth. Sections show, however, spherical secondary deposits of this peculiar fibrous tissue (up to $3 \mathrm{~cm}$. in diameter) immediately below the capsule of the liver (Figs. 3 and 4).

Case No. 7M [King George's Hospital 49534].-This man died at the age of 78 , and death was certified as due to 'carcinoma of the tonsil'. He had been exposed to mixed asbestos dust for 20 years from 1942. Annual chest radiographs from 1948 onwards all showed extensive calcified pleural thickening. This was believed to be due to old tuberculous infection, although he stoutly denied any previous illness. Two months before death he was admitted to King George's Hospital with a strangulated hernia which was reduced without operation. Refusing any investigation, he returned home where he rapidly went downhill and died from the effects of a large growth in the pharynx.

Necropsy on September 26, 1962 by Dr. D. Rushton showed brown atrophy of the myocardium with moderate generalized atherosclerosis. The left tonsil was replaced by a large fungating growth centrally ulcerated, filling the back of the throat. There were secondary deposits in the upper left cervical nodes, and the growth extended into the cellular tissues of the neck. The lungs showed considerable fibrosis and pigmentation with a mass of fibrous tissue $5 \mathrm{~cm}$. across in the left upper lobe which had a central cavity. The pleurae were obliterated and the diaphragm was thickened and calcified. The upper surface of the liver was covered with firm white fibrous tissue up to $1 \mathrm{~cm}$. thick. There were numerous small nodules and plaques in the visceral and parietal peritoneum in the upper part of the peritoneal cavity, but these did not clearly invade any of the organs. The spleen was similarly encased in white thickening of the capsule, but the bowel was unaffected.

Histological examination of these tissues shows a typical transitional-celled carcinoma of the tonsillar lymphadenoid tissue (Fig. 5) quite distinct from the type of growth seen in the peritoneum in the other cases. On the other hand, the thickening of the capsule of the liver, which does not invade the parenchyma, is of the same tissue as that seen in the patients dying from the effects of abdominal growths. It is predominantly spindle-celled with a smaller number of diffusely distributed hyperchromatic polygonal cells, some of which are forming irregular clefts (Fig. 6). The lungs show relatively little fibrosis with a moderate amount of black pigment and a few asbestos bodies. Birefringent spicules are present in the surface layers of the liver mass and are $1 \times 0.5$ microns in size.

Case No. 2F (No hospitalization).-This woman died at the age of 67 from coronary thrombosis and chronic bronchitis. She had been exposed to mixed asbestos dust under the bad conditions of 1916 to 1919 in the weaving department. She was diagnosed as a case of moderate asbestosis in 1946. She first complained of indigestion in 1960, 19 months before death. Gradually increasing ascites developed. The terminal illness began three months before death with anorexia, flatulence, constipation, and increasing ascites. Death was caused by an acute coronary occlusion.

A necropsy by Dr. D. Rushton confirmed the coronary occlusion and patchy myocardial fibrosis. There was no 


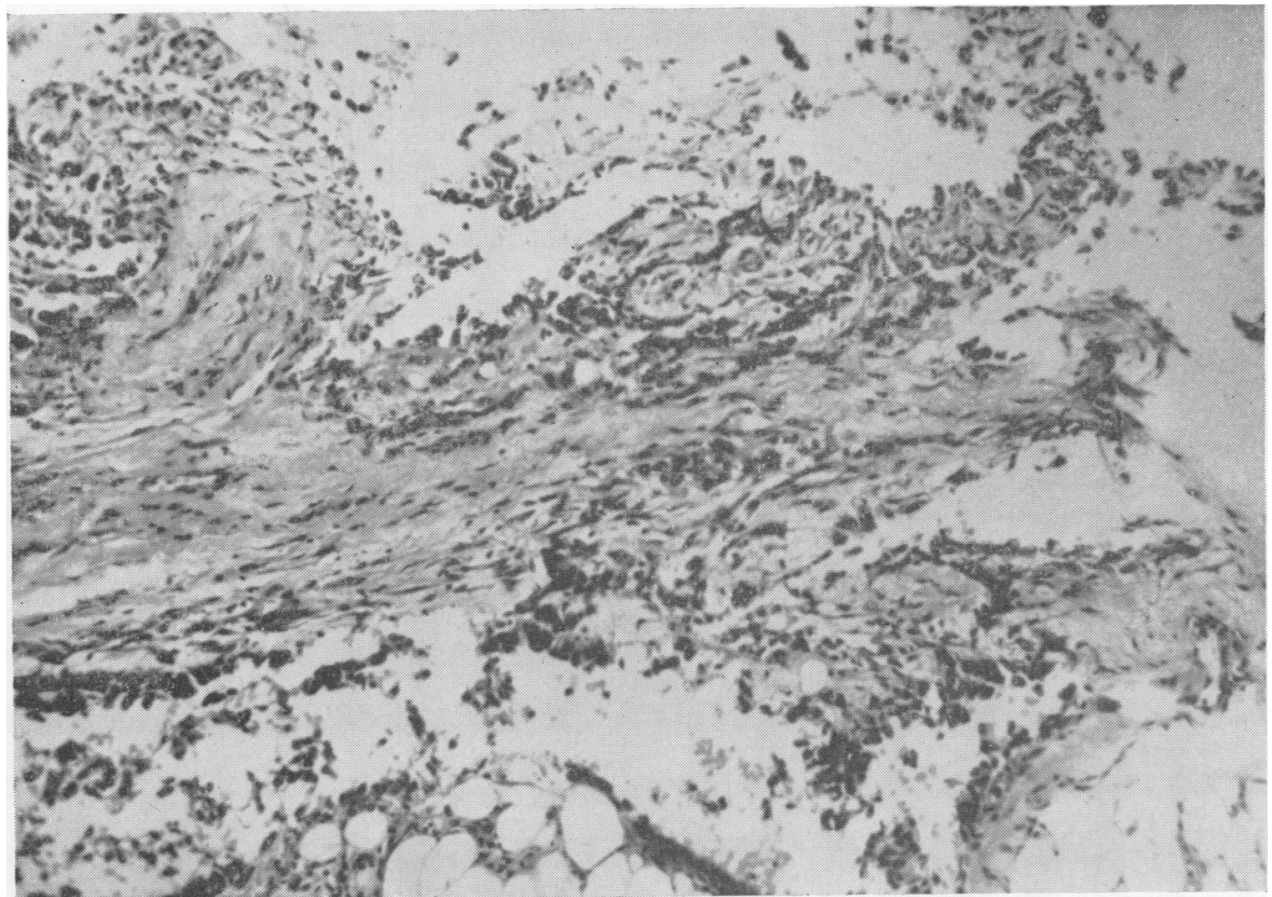

FIG. 1.-Biopsy section, $\times 130$.

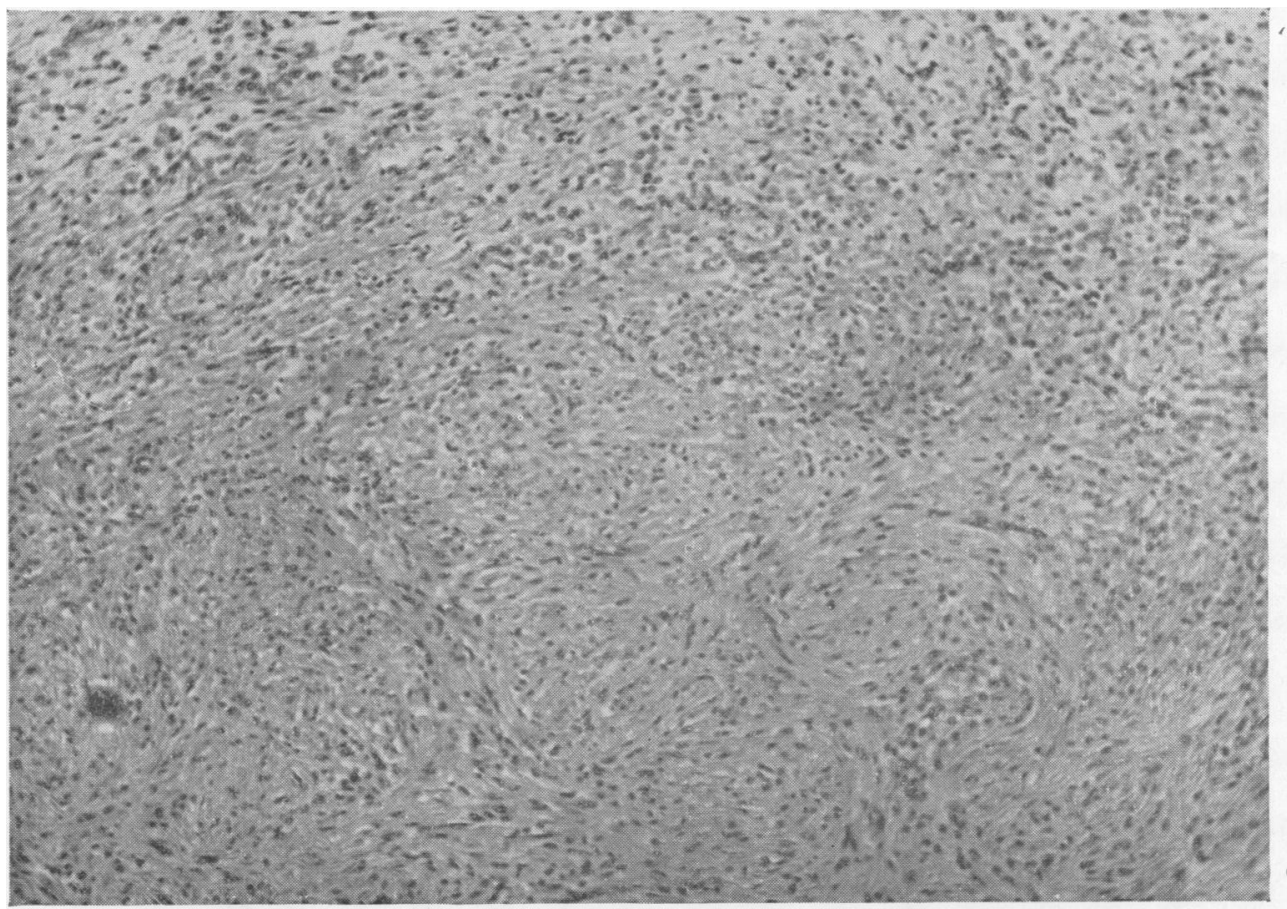

Fig. 2.-P.M. section, $\times 130$. 


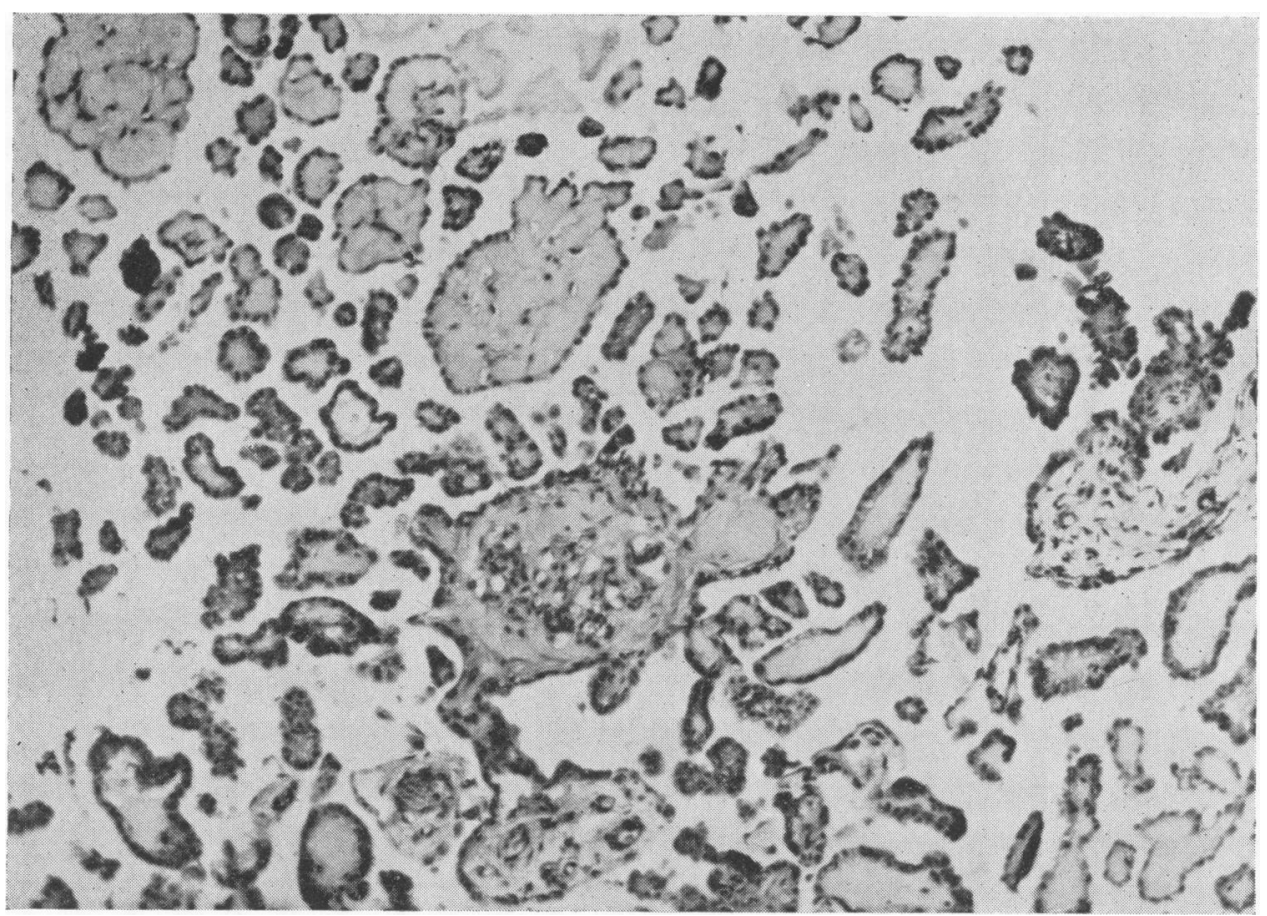

Fig. 3.-Biopsy section, $\times 130$.

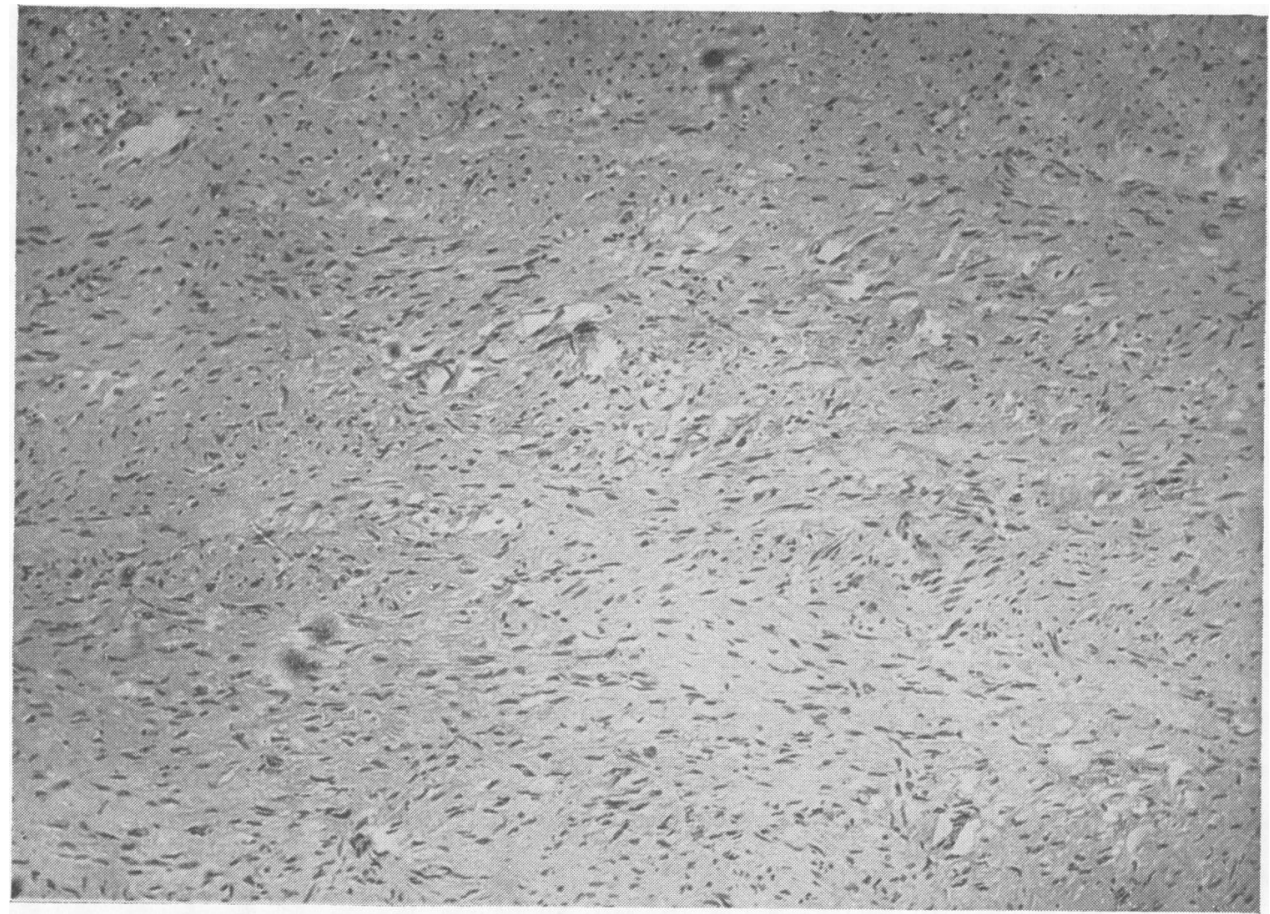

Fig. 4.-P.M. section, $\times 130$. 


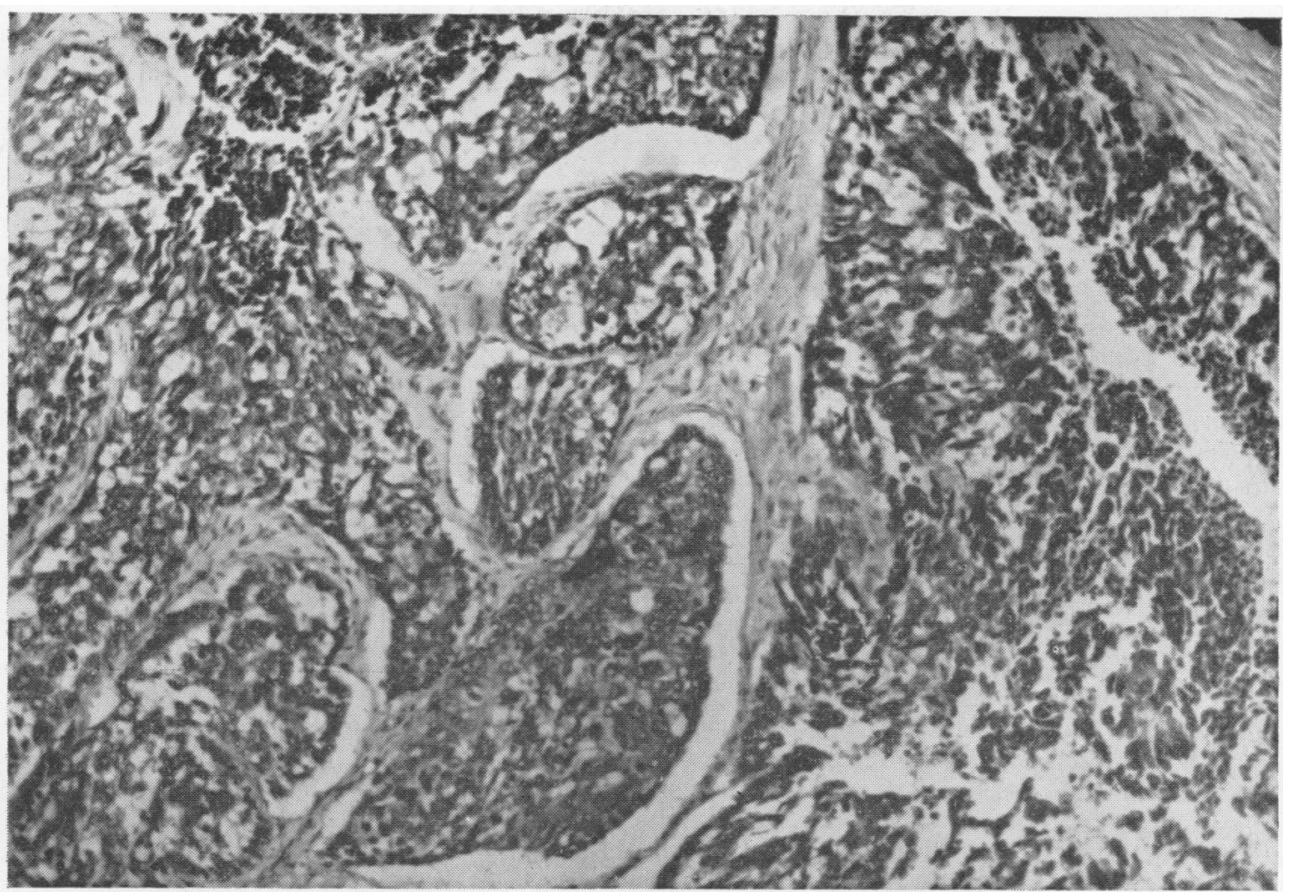

Fig. 5.-P.M. section, $\times 130$.

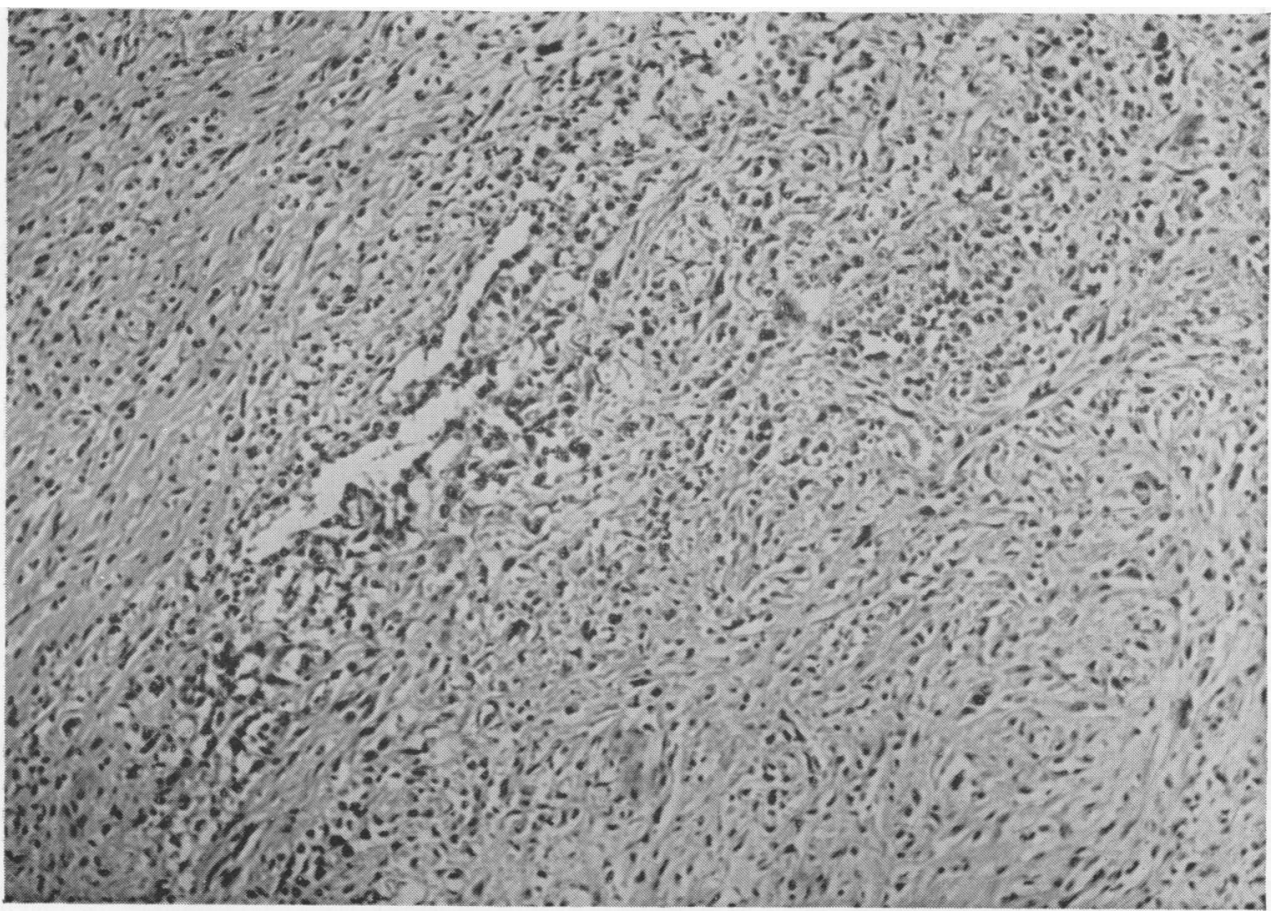

FIG. 6.-P.M. section, $\times 130$. 
cor pulmonale. Bilateral pleural plaques were present and a $5 \mathrm{~cm}$. calcified pleural plaque. The lungs showed a moderate degree of old fibrotic collapse, some carbon pigment, and shotty thickening consistent with patchy fibrosis. There was a chronic peptic ulcer. Widespread and generalized thickening of the peritoneum with numerous irregular flattened nodules and plaques was present, and there was a confluent firm mass $5 \mathrm{~cm}$. across in the omentum. Discrete nodular deposits were seen in the pancreas and porta hepatis. The right lobe of the liver contained a large yellowish-white rounded nodule mainly in its substance but in contact with the serous surface anteriorly.

Histological examination of the lungs confirms asbestosis. The small bowel shows greatly thickened serosa, which is mainly spindle-celled, but also contains spaces lined by cuboidal and flattened cells. A few lymphocytes and some fibrinoid necrosis are unusual features, and similar tissue in the liver shows extensive necrosis.

Case No. 3M [London Hospital 190984].-This man died at the age of 52 with "peritoneal endothelioma and asbestosis'. He had been exposed to mixed asbestos dust from 1930 to 1934 in the carding department. Pulmonary asbestosis was diagnosed during his stay at the London Hospital in 1963. This admission was for pain in the loins and under the right costal margin, anorexia, loss of weight, general malaise, and pyrexia. At laparotomy the liver was found to be slightly mottled and granular with many adhesions between the lobes of the liver and the diaphragm on the right. No obvious masses were found in the liver, but in the porta hepatis there was a big irregular mass continuing into the liver, and there were also multiple para-aortic glands. Some of the mass was excised for biopsy. The patient was followed up in the out-patient department but died at home two months after discharge from the ward.

The following is the biopsy report from the London Hospital: 'Malignant papillary-tubular neoplasm, possibly but not characteristically renal in origin. Primary peritoneal endothelioma is suggested by the persistent cleft formation and the large dark cells'.

At necropsy on July 29, 1963 Dr. D. Rushton found extensive adhesions at the base of the right pleural cavity and the dorsal region of the lung. The lungs were tough to feel, firmer than normal, collapsed, and oedematous. There was old tuberculosis at the right apex, but the gross characteristics were not obviously asbestotic. Sections from the lung, however, showed fibrosis and asbestos bodies.

The peritoneal cavity contained a large amount of turbid yellow fluid. There were widespread numerous small white nodules scattered over the whole surface of the small bowel, the large bowel, and the peritoneal surface generally. The diaphragm was extensively adherent to the upper surface of the liver. There was a large growth $4 \mathrm{in} .(101.6 \mathrm{~mm}$.) in diameter and white in colour near the liver hilum, which did not involve the stomach. The entire pancreatic head was replaced by growth. Dr. Rushton registered the cause of death as 'carcinomatosis due to carcinoma of the pancreas'. The necropsy sections from the mass are predominantly necrotic fibrous tissue but the typical clefts and papillary formations are seen.

Case No. 4F [King George's Hospital 98753].-This woman died at the age of 61 with 'generalized carcinomatosis of the abdomen'. She had had eight years' exposure to mixed asbestos dust from 1916 in the jointing and mattress department in the days before the hazard was appreciated. Asbestos bodies were found in the sputum in 1956 and a radiograph showed some degree of asbestosis. The terminal illness began three months before death with abdominal swelling, discomfort, and loss of weight. When admitted to King George's Hospital she was found to have abdominal masses, an enlarged liver, and ascites. She died within a few days of admission in 1962.

At necropsy Dr. J. Spencer found pleural adhesions and thickening with little pulmonary fibrosis. The entire peritoneum, including the diaphragm, was studded with firm creamy new growth, which was also present on the surfaces of the liver and spleen. The ovaries and uterus were embedded in a mass of tumour.

Histological examination of the necropsy material confirms extensive pulmonary asbestosis. The bowel wall is thickened by $8 \mathrm{~mm}$. of reactive fibrous tissue in which there are some clefts lined by pseudo-epithelium. Birefringent spicules $5 \times 1$ microns can be found.

Case No. 5M [London Hospital 141164].-This man was discharged from the London Hospital with an inoperable malignant growth in the peritoneum. At the time of writing he is alive and apparently well 10 months after biopsy. He had been exposed to mixed asbestos dust from 1937 to 1940 and again from 1945 to 1955 , when asbestosis was diagnosed. The development of a pleural effusion in 1961, with its sinister implications, led to thoracotomy. There was no evidence of malignancy, but a collapsed right lower lobe and a large amount of clear straw-coloured fluid were removed. The removed lobe was clearly asbestotic. One year after lobectomy he was re-admitted for investigation of dyspepsia with pain, vomiting, flatulence, and ascites. At laparotomy there was marked straw-coloured ascitic fluid and multiple small metastases covering the peritoneum. The omentum was shrivelled and indurated, and on the upper surface of the left lobe of the liver was a peritoneal plaque. No secondaries were seen in the liver. The condition was considered to be inoperable, and a biopsy was taken from the omentum.

Specimens from both operations were kindly supplied by Dr. D. Hourihane of the Bernard Baron Institute. The lobectomy specimen confirms the presence of advanced asbestotic fibrosis, but there is no tumour. The abdominal biopsy shows cuboidal and columnar cells forming clefts, solid masses, and alveoli. The histological appearances in this case are more reminiscent of adenocarcinoma than in any of the other cases described, but, in view of the characteristics seen in the whole series and the absence of any mucus secretions, this diagnosis is discarded and the case is included. 
Case No. 8M [Harold Wood Hospital 55085].-This man died at the age of 47 with 'carcinomatosis abdomini'. $\mathrm{He}$ had been exposed to mixed asbestos dusts for 25 years from 1929 to 1954 . For the greater part of that time he was most meticulous in the wearing of a respirator in his position as foreman. For the next five years he was foreman of the gardening staff. Pulmonary asbestosis was never diagnosed although he was radiographed annually. His terminal illness began when he presented to one of us six months before death complaining of burning abdominal pain. He was admitted to hospital for investigation. At laparotomy the surgeon reported mucoid looking carcinomatous deposits in the peritoneum, liver, and abdominal organs. There were several pints of viscous free fluid. A biopsy was taken, on which Dr. $\mathbf{H}$. Bennison reported mainly anaplastic growth with occasional capillary and tubular forms. A primary pancreatic growth was thought likely.

The patient died two days later. At necropsy Dr. Bennison found that the coils of the bowel were held together by numerous soft nodules of growth, which were also present on the parietal peritoneum, on the liver surface, in the abdominal nodes, and in the pancreas.

Histological examination of necropsy material confirms pulmonary asbestosis. The bowel is invaded by growth from outside. This shows the same histological structure of clefts in a solid, predominantly fibrous tumour with the capillary and alveolar pseudo-epithelial formation seen in the other cases. There are occasional birefringent particles. Although the tumour does not appear to be highly malignant, it is clearly invading the muscle of the bowel.

Case No. 9M [London Clinic 1961].--This patient died at the age of 57 with ' carcinomatosis peritonei'. He had been exposed to mixed asbestos dust for about 27 years. His exposure was minimal at any one time because his work had always been clerical, supervisory, and technical. Asbestosis was diagnosed in 1948, but he did not wish to apply for certification. The terminal illness began about six months before his final admission to the London Clinic in 1961 because of abdominal pain which radiated to the left flank.

A peritoneal biopsy (2117/61) was reported to show 'an extensive fibrous reaction amongst which there are clefts and acinus-like formations lined by cells with serosal characters'.

At necropsy Dr. F. E. Camps showed a pulmonary embolus, pneumonia, minimal pulmonary asbestosis, a hiatus hernia, and diffuse infiltration of the peritoneum by hard white tissue.

The histological appearances of the necropsy tissue are very similar to those of the first case described, case $6 \mathrm{M}$ (London 40336/47), showing both stroma and alveolar formations. The lungs show a moderate degree of asbestosis.

Case No. 10M [London Hospital 27245/56].-This case was fully described by Keal (1960) as his case number 24 . He had been exposed in the same factory as the previous cases in this series to mixed asbestos dust for four years from 1931, and less heavily for 17 years from
1937. Pulmonary asbestosis was diagnosed on periodic examination in 1954. Histological examination of material from the London Hospital necropsy, kindly provided by Dr. J. Landells, confirms pulmonary asbestosis and bronchopneumonia. One section shows ileum entirely surrounded by tumour. This is predominantly alveolar with a mono-layer of cuboidal lining cells which are regular in size. Some typical 'adenocarcinomatous' formations are seen, and some dilated alveoli contain papillary processes. There are however some epithelial lined clefts quite unlike carcinoma in their irregular slit-like configuration.

Case No. 11M [Hammersmith Hospital 227252].This case was fully described by Heard and Williams (1961) as their case number 6 . He originally presented to one of us (W.J.S.) because he was concerned over his 'middle-aged spread'. He had had abdominal discomfort and distension for eight months. Dr. B. Heard has kindly provided histological sections from the biopsy (June 18, 1959) and necropsy (December, 1959). Histological examination of the biopsy specimen shows a nodule about $1 \mathrm{~cm}$. across with fronds of very vascular tissue and some small alveolar and solid masses. One nodule contains birefringent needles $5 \times 1$ microns.

\section{Discussion}

In the past five and a half years we have seen 52 cases of asbestosis at necropsy. Nineteen (36\%) had carcinoma of the lung, none of which was pleural in origin. Fourteen $(27 \%)$ had abdominal tumours, nine $(17 \%)$ of which appeared to originate in the peritoneum. There was a single case of carcinoma of the breast $(2 \%)$. A possible total of 9,550 people have been occupationally exposed to asbestos at this one factory since 1913. Including two cases, the necropsies of which neither of us attended, this gives an incidence of peritoneal tumour of about 1 in 1,000 of those exposed. It should be noted, however, that as many as 46 years may pass before the onset of the syndrome, and in none of our cases was the interval less than 20 years. A number of cases may have died elsewhere since no special effort has been made to follow up all the people occupationally exposed and the eventual incidence may be higher. It seems clear that this is another clinical condition that must be recognized as part of the asbestosis syndrome, just as carcinoma of the bronchus is now recognized. Furthermore, the condition is associated with industrial exposure though there may not be enough pulmonary fibrosis to qualify for certification.

In previous series (Keal, 1960; Bonser et al., 1955) of somewhat similar cases, the majority of patients were women. Indeed Keal concluded that most of his cases were ovarian carcinoma, as did the pathologists in two of the three female cases reported here, but eight of our 11 cases were men, and we have also 
been able to examine material from a white South African man aged 44 by the courtesy of Dr. J. C. Wagner. This man (EN705253) lived near asbestos dumps in his youth but was not occupationally exposed. A single section shows a cellular reaction in fibro-fatty tissue of the peritoneum and demonstrates a transitional form between columnar pseudoepithelium and irregular fibrous tissue. There are no asbestos bodies nor any birefringent material. A hyaluronidase test with toluidine blue was negative on this section but the form of fixation is unknown. Histologically it is similar to and is probably pathogenetically identical with the London cases.

There can be no doubt that the predominant abnormal material in the histological sections is of fibrous tissue origin, and such cells as resemble serosal epithelium appear to be derived from them. In the early stages, seen in peritoneal biopsy, the lesions are more cellular, and later they become more fibrous. Progressive massive fibrosis in the related industrial conditions of silicosis is considered by the authors to be somewhat analogous, and silicotic granuloma due to talc is another comparable condition. Since much inhaled foreign material passes into the gut (Hilding, 1963) it is probable that some at least will enter the abdominal lymphatics. We have suggestive evidence of its presence in these peritoneal tumours, and further searches by electron microscopy and by $x$-ray diffraction methods at present being carried out may confirm this. However, in these patients with peritoneal tumours the pulmonary changes due to asbestos are below average in severity (disability has been commonly assessed at 10 to $30 \%$ ). It may well be that the shorter life span of the severely affected worker is the reason why the syndrome is not more common. Another cause of confusion is the frequent diagnosis of some other form of neoplasm of which we have examples in carcinoma of the stomach, ovary, pancreas, and tonsil, as well as the unclassified cases of carcinoma of the peritoneum.

Wagner, in a series of publications (Wagner et al., 1960; Sleggs, Marchand and Wagner, 1961) has claimed that tumours of the mesothelium are peculiarly liable to occur in asbestosis. In one African community he has claimed a very high incidence indeed (personal communication) despite often minor exposure, in some cases confined to childhood. We do not exclude the possibility that the masses which occur in the abdomen in the syndrome we describe are mesotheliomas and therefore true neoplasms, but we do not believe that our evidence, or any other of which we are aware, justifies such a confident assumption.

The earliest reference to similar masses which we have encountered is von Rokitansky's description of primary 'colloid cancers' of the peritoneum. Neither he nor any subsequent author offers any convincing proof of their malignant character, and there does not appear to have been any great advance on the opinion of Lubarsch (1895) that 'There is scarcely another variety of tumour which is so ill defined and which admits of so much doubt as to its precise nature'. Histological studies, such as that of Stumpf (1954), merely demonstrate what is clear from this material, that serosal cells may assume many weird shapes as well as several distinct organized patterns under abnormal circumstances. The tissue cultures of Stout and Murray (1942), while clearly demonstrating the ability of mesothelial cells to assume an epithelial appearance, are at least as consistent with the masses being due to reactive processes as to their being neoplastic. To quote further, while Ackerman (1954) states that 'It is the majority opinion that although primary peritoneal tumours are rare they do exist', Willis (1952) considers that 'It will be well to preserve an open mind regarding (their) exact histogenesis', and Brown and Johnson (1951) frankly consider them the 'end result of a low grade inflammatory process with organization of the exudate'.

It is abundantly clear that speculation is more readily available than fact concerning these tumours, and we consider it more helpful to add to the latter than to the former. We are impressed by the lack of occupational data in nearly all of the clinical histories with the exception of the most recent. It is our opinion that these masses do not in fact closely resemble neoplasms, and, apart from these controversial cases, we have not encountered a mesothelioma in several thousand necropsies (see Enticknap, 1952). In the uniform presence of a history of exposure to an industrial irritant that has not yet been shown to be oncogenic, we think it unwise to give the name of a specific neoplasm to this syndrome and prefer, with Miller and Wynn, who recorded the first British case in 1908, to say 'We shall not attempt to give an explanation . . . we merely record the fact(s)'.

The exact nature of the tumours may only be elucidated by their experimental production in animals, and details of Wagner's (1962) experiments are awaited with interest. We have in this series had an opportunity to examine by conventional methods a large amount of human tissue showing these changes and feel it is unlikely that such studies will permit more than an informed opinion. As we have been unable in the course of studying these cases to form a definite opinion as to the nature of the abdominal masses, we prefer to evade the issue by referring to the predominant tissue in them as 'wild fibrous tissue', and we believe it may be a direct 
reaction to the presence of foreign material in the serosal cells. We propose that the condition be called the peritoneal tumour of asbestosis until its exact nature becomes clear.

In the fifth century A.D. $\alpha \sigma \beta \epsilon \sigma \tau \omega \sigma \iota \varsigma$ was first used to denote plastering or stuccoing. In our view the term asbestosis was most aptly chosen for the pathological effect of asbestos. Asbestos may 'plaster' the lung, the pleura, or the peritoneum.

We would like to express our thanks to the many people who have helped us to collect the information on which this report is based. They are too numerous to list individually, but without their generous help it could not have been written. H.M. Coroner for West Essex has kindly given us permission to report the cases which came within his jurisdiction. Mr. D. R. Hall, laboratory photographer, was responsible for the photographs.

\section{REFERENCES}

Ackerman, L. V. (1954). Atlas of Tumour Pathology, Sect. 6, fasc. 23 and 24, p. 100. Armed Forces Institute of Pathology, Washington.
Bonser, G. M., Faulds, J. S., and Stewart, M. J. (1955), Amer. J. clin. Path., 25, 2.

Brown, W. J., and Johnson, L. C. (1951). Milit. Surg., 109, 415.

Enticknap, J.' B. (1952). Guy's Hosp. Rep., 101, 273.

Gloyne, S. R. (1951). Lancet, i, 810.

Heard, B. E., and Williams, R. (1961). Thorax, 16. 264.

Hilding, A. C. (1963). Arch. environm. Hlth, 6, 67.

Keal, E. E. (1960). Lancet, ii, 1211.

Leicher, F. (1954). Arch. Gewerbepath. Gewerbehyg. 13, 382.

Lubarsch, V. A. (1895). Lubarsch-Ostertag Ergebnisse der Path. u.

Anat. Bd. ii, p. 265. Wiesbaden.
Lynch, K. M., and Smith, W. A. (1935). Amer. J. Cancer, 24, 56.

Mancuso, T. F., and Coulter, E. J. (1963). Arch. environm. Hlth, 6, 210 .

Miller, J., and Wynn, W. H. (1908). J. Path. Bact., 12, 267.

Rokitansky, C. von (1854). Manual of Path. Anat., p. 265. Sydenham Soc. Trans., London.

Selikoff (1963). Personal Communication. Selikoff, I. J., Churge, J., and Hammond, E. C. Paper presented at a Joint Meeting of Sections on Radiology and Diseases of the Chest of the American Medical Association and the American College of Chest Physicians on June 17, 1963 at Atlantic City, N.J.

Sleggs, C. A., Marchand, P., and Wagner, J. C. (1961). S. Afr. med. J., 35,28 .

Stout, A. P. and Murray, M. R. (1942). Arch. Path., 34, 951.

Stumpf, H. H. (1954). Cancer, 7, 142.

Wagner, J. C. (1962). Nature (Lond.), 196, 180. Munday, D. E., and Harrington, J. S. (1962). J. Path. Bact., 84, 73 .

, Sleggs,

Willis, ${ }^{17}$. (1952). The Spread of Tumours in the Human Body, 2nd ed., p. 57. Butterworth, London.

Winslow, D. J., and Taylor, H. B. (1960). Cancer, 13, 127. 